\title{
Histochemical Studies on Brain Edema
}

\author{
Yawara Yoshitoshi, Toshitsugu OdA, Kiyoshi SEKI, Yoshiji \\ Yamane, Masami Yamanaka, Keizo Konde \\ and Kazuo MorI
}

(First Department of Internal Medicine, Faculty of Medicine, University of Tokyo)

Brain edema is believed to occur not only in the cases of cerebral diseases, but also in others such as uremia, hepatic coma and heart failure. Although it is very important problem to study its pathogenesis even in clinical medicine, it has not come to a sufficient understanding.

The studies on brain edema at the initial stage were carried out mainly from the standpoint of morphology, then extended to the physical and chemical ones, including electron microscopic study. Furthermore, histochemical method has been introduced in this field lately. In Japan also, Ambo reported some histochemical studies of brain edema concerning some enzyme activities.

On the other hand, there have been many ways to produce a experimental brain edema on animal. Since Magee's report in 1957 using Alkyl Tin compounds for this purpose, many reports of pharmacological properties on these agents were followed. Thus Aldrige and Cremar found that triethyl tin compound (TET) induced mitochondrial swelling in the liver cell and inhibited its oxidative phosphorylation.

We also have used TET in the experimental study of brain edema, esp. from the bio-and histochemical standpoint. Our findings, so far, are as follows;

1) Water, sodium and chloride contents in brain tissue incresead, while potassium showed a only slight decrease.

2) Histologically, light microscope showed few changes in superficial layer of cerebral cortex, but the perivascular and pericellular spaces were found to be dilated progressively in deeper layers, and in the white matter a prominent vacuolisation of various size was seen, resulting in sponginous appearance.

3) Electron microscopy proved no apparent changes on the capillary wall, but huge cavitation between splitted lamellae of the myelin sheath.

The present paper is to investigate some histochemical aspects of brain edema, comparing with the biochemical analysis.

\section{Experimental methods}

Adult rats were used as the experimental. In order to produce brain edema in rat, TET was administered intravenously by the dose of $10 \mathrm{\gamma} / \mathrm{gram}$ body weight. The treated rat showed muscle weakness on hind legs, followed by gait disturbance, akinesia, generalized tremor and finally death in a few 
days. All the experiment were carried out on the second or third day, that is, just before their death. After decapitation, the brain was taken out of the skull as soon as possible, and put into dry ice aceton mixture. The histological preparations were made by cryostat under the controlled temperature of $-20^{\circ} \mathrm{C}$ and each $10 \mu$ thick.

Histo- and biochemical methods are listed in Table 1.

Table 1. Histo- and biochemical methods

$\begin{array}{ll}\text { Histochemical methods } & \text { : Cohen } \\ \text { Lactate dehydrogenase } & : \text { Gomori } \\ \text { Alkaline phosphatase } & : \text { Burstone } \\ \text { Cytochrome oxidase } & : \text { Wachstein \& Meisel } \\ \text { ATP-ase } & : \text { Nachlas } \\ \text { Succinate dehydrogenase } & \\ \text { Biochemical methods } & : \text { Nailands } \\ \text { Lactate dehydrogenase } & : \text { Reitman-Frankel } \\ \text { GOT } & : \text { Kind-King } \\ \text { Alkaline Phosphatase } & : \text { Wayne-Kielley } \\ \text { ATP-ase } & : \text { Slater } \\ \text { Succinate dehydorgenase } & \end{array}$

\section{Results}

1) ATP-ase : normally nerve cells and capillaries are well stained in brain tissue. But in TET group ATP-ase activity in brain tissue was found to be markedly reduced. (Fig. 1 and 2)

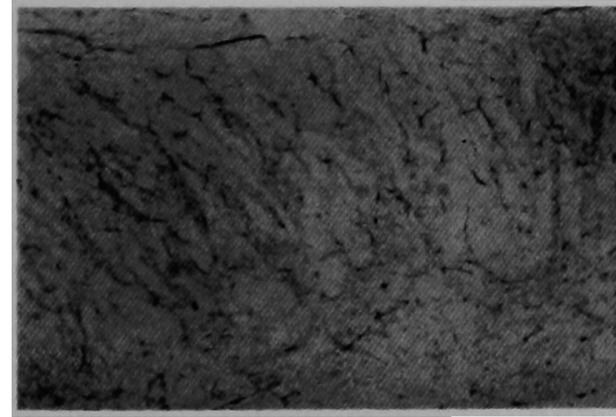

Normal

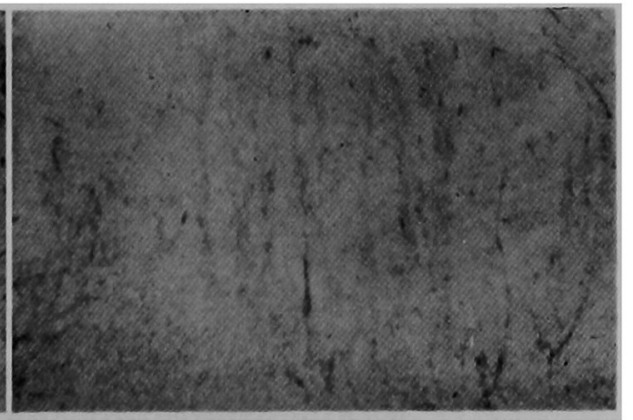

Brain edema (TET)

Fig. 1 ATPase-staining. (Crus cerebri)

2) Succinate dehydrogenase: normally well stained in nerve cells, but this was significantly reduced in TET group also.

3) As to lactate dehydrogenase, glutamate dehydrogenase and alkaline phosphatase, no remarkable difference was found between normal and TET groups.

4) On the other hand, enzymatic activity in brain tissue homogenate were illustrated in Table 2; TET group showed no significant changes on LDH, 


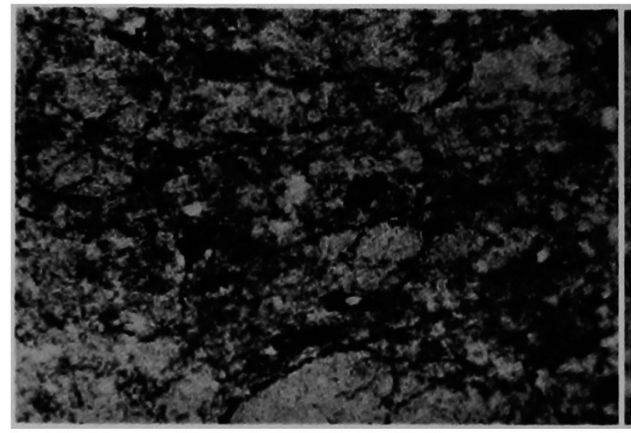

Normal

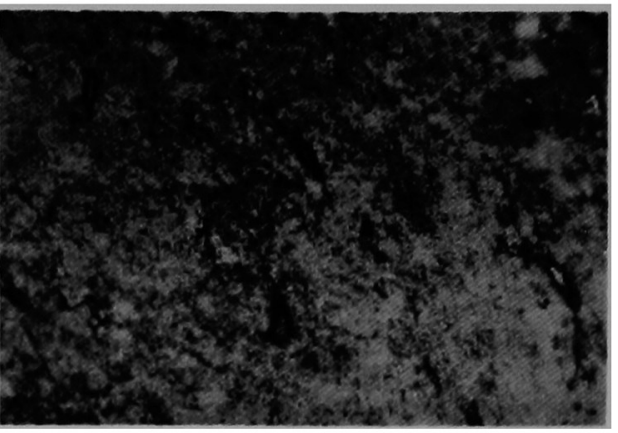

Brain edema (TET)

Fig. 2 Suc DH-staining (Striatum)

GOT and Alk. P-ase comparing with normal group, but ATPase and SucDH were found to be reduced in TET group.

Table 2. Enzyme activity and oxygen consumption in brain tissue homogenate

\begin{tabular}{llc} 
& \multicolumn{1}{c}{ normal } & brain edema (TET) \\
ATP-ase & $130 \pm 17 \mu \mathrm{mol} / \mathrm{min} / \mathrm{g}$. prot. & $88 \pm 10$ \\
SucDH & $16.2 \pm 1.9 \mu 1 / \mathrm{h} / \mathrm{mg}$. prot. & $10.0 \pm 2.0$ \\
LDH & $251 \pm 23 \mathrm{u} / \mathrm{g} . \mathrm{prot}$. & $229 \pm 37$ \\
GOT & $513 \pm 32 \mathrm{u} / \mathrm{g} \cdot \mathrm{prot}$. & $572 \pm 40$ \\
Alk. P-ase & $19.0 \pm 3.1 \mathrm{u} / \mathrm{mg}$.prot. & $21.3 \pm 4.4$ \\
$\mathrm{O}_{2}$ consump. & $18.2 \pm 2.0 \mu 1 / \mathrm{mg} . \mathrm{h}$. & $14.7 \pm 1.9$ \\
\hline
\end{tabular}

\title{
Conclusion
}

These bio- and histochemical findings are coincidental each other so far as the present studies are concerned. Although these results do not directly give any conclusion about the mechanism of brain edema induced by TET, it is likely to assume that some enzymatic alterations may play some roles on producing brain edema. Whether inhibition of oxidative phosphorylation is the main mechanism in brain edema as Aldrige and Cremar reported, is not concluded here. Further study is now in progress in this respects.

\section{Radioautographische und Experimentelle Untersuchungen der Ammonsformation.}

\author{
N. Otsuka und M. Kawamoto
}

Anatomisches Institut der Medizinischen Akademie, Kyoto

Nach der intravenösen Injektion einer schwach alkoholischen alkalischen Dithizonlösung färbt sich die Rindenplatte des Gyrus dentatus und der Fe- 